\title{
انتاج أوعية دموية مخبرياً في طبق بتري
}

نور شاهين noor rafiq 2006@hotmail.com

نجح باحثون في نطوير أنسجة أوعية دموية ثلاثية الأبعاد مصنعة في المختبر بدءًا من خلايا جذعية،

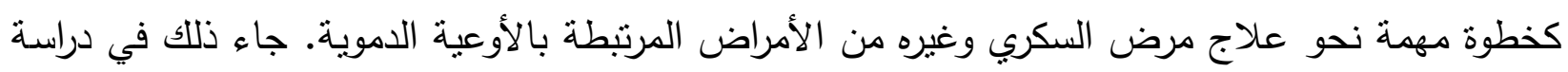

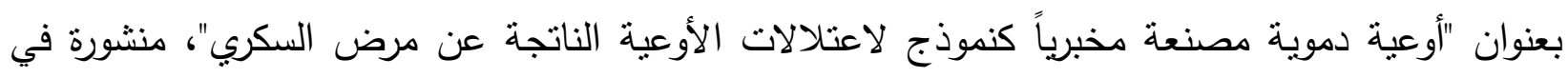
مجلة الطبيعة "نيتشر".

وأوضح الباحثون في الأكاديمية النمساوية للعلوم وجامعة كولومبيا البريطانية، أن مرض السكري يسبب تلف

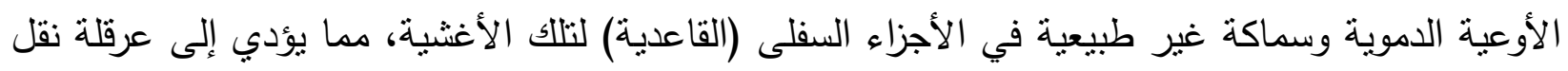

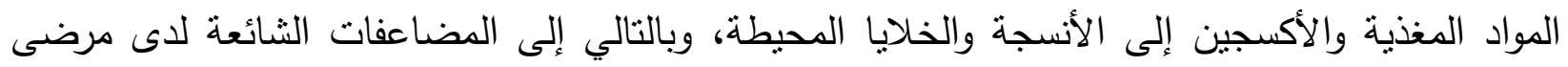
السكري، كأمراض العيون والعمى وأمراض القلب والسكتات الدماغية وأضرار الكلى.

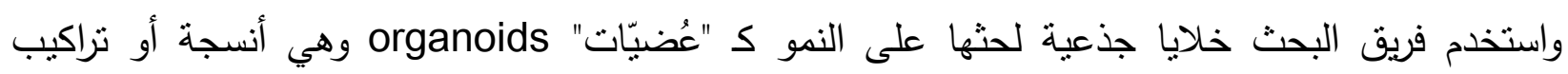
خلوية ثلاثية الأبعاد تقوم بوظيفة الإطار أو السقالة التي تتمو عليها الخلايا لتصبح أوعية دموية.

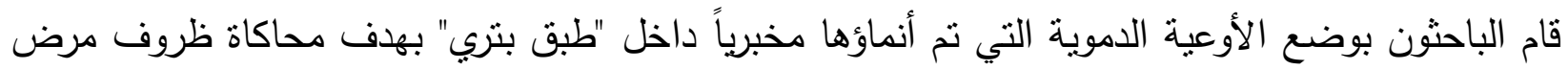

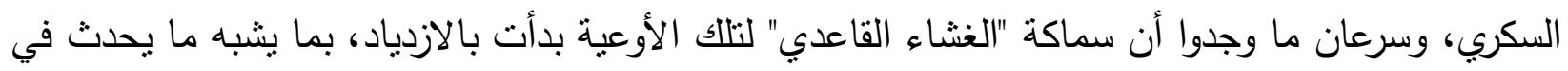

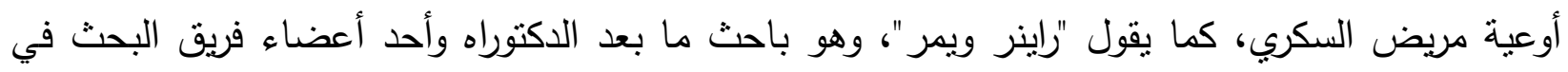
الأكاديمية النمساوية للعلوم. عكف بعد ذلك أعضاء الفريق على البحث عن مادة كيميائية يمكن أن تمنع تثنُّن الأغشية الوعائية، ووجدوا

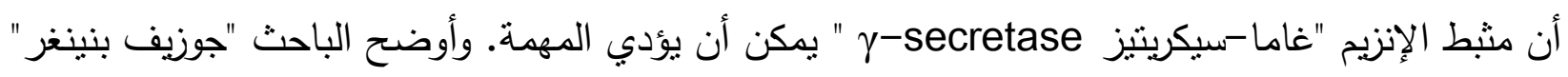

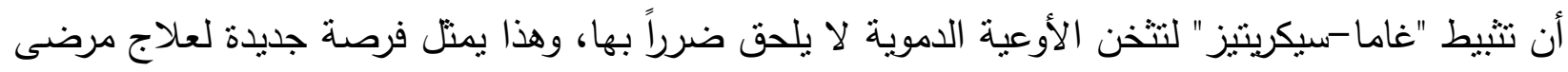
السكري.

ويعتقد الفريق أن هذا البحث لن يفيد في حالة مرض السكري وحسب، بل وفي حالات أخرى عندما تكون

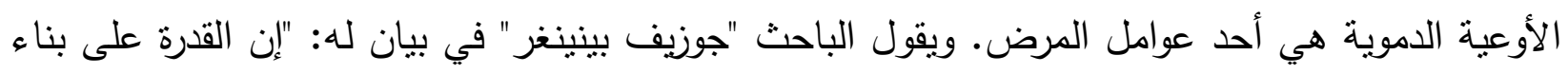

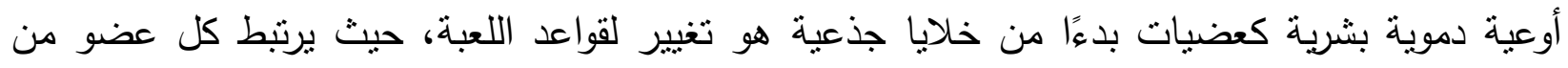

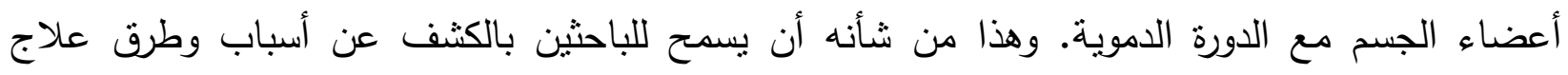


مجموعة متتوعة من الأمراض الوعائية، كمرض الزهايمر، وأمراض القلب والأوعية الدموية، ومثاكل التئام

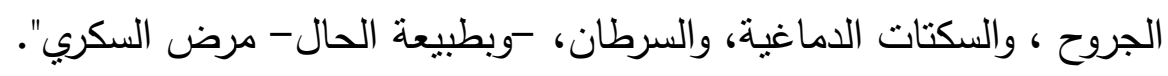

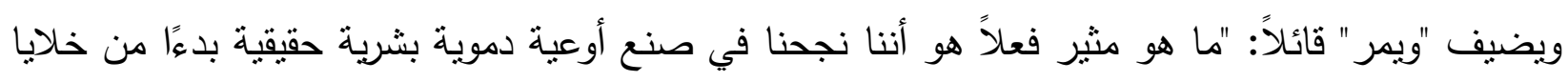
جذعية ... وأن العُضيّات الناتجة تشبه إلى حد كبير الثعيرات الدموية البشرية، حتى على المستوى الجزيئي، ويمكننا الآن استخدامها لدراسة أمراض الأوعية الدموية مباشرة على الأنسجة البشرية".

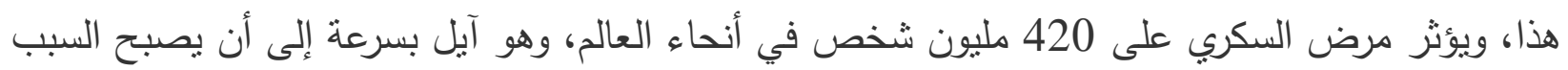
الرئيسي للوفاة والعجز • إذ يسبب مرض السكري على المدى الطويل أضرارًا على كل الأجهزة الرئيسية تقريبًا في الجسم، وهو ناجم أساسًا عن مستويات مرتقعة ودائمة لسكر العنب (الجلوكوز) في الدم. لمديل

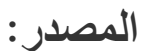

https://www.news-medical.net/news/20190117/Blood-vessels-can-now-be-

created-perfectly-in-a-petri-

dish.aspx?fbclid=IwAR2ThXFljJ10bgq27H0b3o7GaiECsS5eLSkpWegeTmZN2uEs JAIVm-7mWwl 